\title{
The Role of Seismological Networks in Civil Protection in Low and High Seismic Hazards
}

\author{
Erzsébet Győri ${ }^{1 *}$, Arman Bulatovich Kussainov², Gyöngyvér Szanyi ${ }^{1}$, Zoltán Gráczer ${ }^{1}$, \\ Kendebay Zhanabilovich Raimbekov², Amangeldi Kurmangazhinovich Togussov ${ }^{2}$ \\ ${ }^{1}$ Kövesligethy Radó Seismological Observatory, Geodetic and Geophysical Institute, Research Centre For Astronomy and Earth \\ Sciences, H-1112 Budapest, Meredek u. 18, Hungary \\ ${ }^{2}$ Kokshetau Technical Institute of the Committee of Emergency Situations of MIA of the Republic of Kazakhstan, KZ-020000 Kokshetau, \\ Akan-Seri Street 136, Kazakhstan \\ * Corresponding author, e-mail: gyori@seismology.hu
}

Received: 13 November 2020, Accepted: 10 February 2021, Published online: 22 February 2021

\begin{abstract}
Earthquakes are one of the most devastating natural disasters on Earth, causing sometimes huge economic losses and many human casualties. Since earthquake prediction is not yet possible, the purpose of civil protection is to reduce damage and protect human lives, in which the seismological networks of different countries play a very important role. Special applications of seismic networks are the early warning systems that can be used to protect vulnerable infrastructures using automated shutdown procedures, to stop high velocity trains and to save lives if the general public is notified about imminent strong ground shaking. In this paper, we describe the aims and operation of seismological networks, covering in more detail the early warning systems. Then we delineate the seismotectonic settings and seismicity in Hungary and Kazakhstan, furthermore, describe the operating seismological networks and the related scientific research areas with emphasis on civil protection. Hungary and Kazakhstan differ not only in the size of their territory, but also in their seismicity, therefore, in addition to the similarities, there are also significant differences between the aims and problems of their seismological networks.
\end{abstract}

Keywords

seismological networks, earthquake early warning system, civil protection, Hungary, Kazakhstan

\section{Introduction}

Earthquakes are one of the most destructive natural disasters on Earth. They occur suddenly and the seismic waves they excite propagate at high velocity in all directions, therefore the possibilities of preparatory and evacuation measures are limited. Thus, the consequences of earthquakes are associated with huge economic losses and numerous human victims. Since earthquake prediction is not yet possible, the purpose of civil protection is to reduce damage and protect human lives, in which the seismological networks of different countries play a very important role.

Civil protection measures strongly depend on the level of the expectable seismicity in a region. Although Hungary and Kazakhstan significantly differ in their tectonic settings, consequently their seismicity, seismological research plays an important role in both countries.

In this paper first we describe the aims and operation of seismological networks, covering in more detail the early warning systems. Then we delineate the seismotec- tonic settings and seismicity in Hungary and Kazakhstan, furthermore, describe the operating seismological networks and the related scientific research areas with emphasis on civil protection. Finally, we summarize the main similarities and differences of the presented seismological networks.

\section{Seismological networks}

\subsection{Operation and purpose of seismological networks}

The first seismic instruments were installed at the beginning of the 20th century. The very first and basic problem was to locate the seismic events and determine their magnitude. For location, at least 3 stations or more are necessary. Before 1960, seismic stations operated independently so their observations were sent to a central location where they were processed together. Today most seismic networks have stations that are linked in a communication network, so data is transmitted to a center in real time. 
Seismic networks have three main purposes [1]:

Seismic alarm

It requires an immediate response after strong earthquakes, serves civil defense purposes, to mitigate the social and economic consequences of a damaging earthquake.

General or specific seismic monitoring

Its aims are the long-term mitigation of seismic risk caused by tectonic earthquakes and human activity (for example preparing seismic hazard maps), studying seismotectonics, monitoring volcanic activity. Seismic networks are one of the most important tools used in monitoring the international nuclear test ban treaty.

Research on the interior of the Earth

The oldest goal of seismology is to study the structure and physical properties of the deeper Earth's interior.

Seismic networks can be very small for the localization of micro-earthquakes and can be global for recording events around the world. The objectives define the technical design of the networks and the types of sensors used. Micro-earthquakes can be recorded with small geophones, while global earthquake recording requires broadband seismometers.

Seismometers are very sensitive sensors recording ground velocity however they are too sensitive for strong motion signals. Therefore, in areas of high seismicity where the main goal of networks is the future seismic risk mitigation, accelerometers are installed to record strong motions.

Special applications of seismic networks are the early warning systems, which are described in more detail in the next section.

\subsection{Earthquake Early Warning Systems (EEWS)}

EEWS is a system of accelerometers, seismometers, communication, and computers designed to provide warning that shaking from an earthquake is expected before it actually arrives. It is not earthquake prediction, as the earthquake has already begun, but can be used to protect vulnerable infrastructures using automated shutdown procedures, and to save lives if the general public is notified about imminent strong ground shaking.

Earthquake early warning systems are based on two principles; first, that the propagation velocity of compressional P-waves is higher than that of destructive shear $\mathrm{S}$-waves and surface waves. Second, seismic waves are far slower than the electromagnetic waves used in modern communication systems.

In EEWS, the first P-waves are recorded by a dense seismic network as soon as these waves reach the nearest stations. The data is then immediately transmitted to a pro- cessing center at the speed of electromagnetic waves and information from multiple stations is combined to determine the epicenter and to predict the strength of ground shaking caused by the slower and more damaging $\mathrm{S}$ waves.

In general, the closer a site is to the rupture, the stronger is the shaking that can be expected, and the shorter is the warning time. This is particularly true for moderate earthquakes, up to about a magnitude of 6.5. Very close to the epicenter, where damage will be the greatest, it may not be possible to provide a warning before the strong shaking begins.

For EEWS, we can talk about alert $\left(T_{a}\right)$ and warning $\left(T_{w}\right)$ time as well as the blind zone $\left(R_{\text {blind }}\right)$ where the warning is not possible. Alert time is the elapsed time between the origin time of the earthquake and the time when the alert is issued [2]. Warning time is the number of seconds after the alert is issued before the S-wave arrives at a particular location. It is spatially variable and can also be negative in the blind zone (or no-alert zone), where the S-wave arrives first.

The warning time of EEWS, can be expressed as:

$T_{w}=T_{S}-T_{a}=T_{S}-T_{P 1}-T_{p r}$,

$T_{S}=\frac{\sqrt{R_{e p i}^{2}+h^{2}}}{V_{S}}$,

$T_{P 1}=\frac{\sqrt{R_{1}^{2}+h^{2}}}{V_{P}}$,

where $T_{S}$ is the time that takes for $\mathrm{S}$-wave to arrive at the object, $T_{P 1}$ is the time that takes for P-wave to arrive at minimum three stations closest to the epicenter, $T_{p r}$ is the sum of data transmission delay and calculation time of the earthquake parameters, $R_{e p i}$ is the epicentral distance of early warning object, $R_{1}$ is the epicentral distance of the farthest of the three stations closest to the epicenter, $h$ is the focal depth, $V_{S}$ and $V_{P}$ are the propagation velocity of S- and P-waves.

Alert and warning time as well as the blind zone depend also on distances between seismic stations $(\Delta x)$ in the network. For example, if we look at an earthquake which occurs at a depth of $10 \mathrm{~km}$ and assume $5.8 \mathrm{~km} / \mathrm{s}$ for P-wave velocity and $3.4 \mathrm{~km} / \mathrm{s}$ for S-wave velocity for the uppermost layer from the IASP91 model [3], as well as $5 \mathrm{~s}$ as the sum of data transmission delay and processing time, we can calculate both the alert time and radius of blind zone in function of station distance, using Eqs. (1)-(3). As it can be seen from Table 1, the larger the station distance, the longer the alert time and the larger the blind zone. 
On the other hand, the ground shaking is stronger, and more damage may be caused in the blind zone than outside it.

Fig. 1 shows the intensity decrease for earthquakes of different magnitudes, based on the intensity prediction equation (IPE) developed by Allen et al. [4]. The figure also shows the radius of the blind zones calculated for different station distances. Since intensity of VI means that the shaking is felt by everyone, people find it difficult to stand, and structures may suffer some damage, we can see from the figure that at a possible earthquake of magnitude 5 , there is no point in building an early warning system. Even at a magnitude of 6, a very dense network is required near the epicenter for the warning to precede the devastating $\mathrm{S}$-wave. However, this requires knowing the

Table 1 Alert time and size of blind zone at different station distances

\begin{tabular}{lcc}
\hline $\begin{array}{l}\text { Station distance } \\
\Delta x(\mathrm{~km})\end{array}$ & $\begin{array}{c}\text { Alert time } \\
T_{a}(\mathrm{~s})\end{array}$ & $\begin{array}{c}\text { Blind zone } \\
R_{\text {blind }}(\mathrm{km})\end{array}$ \\
\hline 10 & 7.4 & 24 \\
20 & 8.8 & 29 \\
30 & 10.5 & 34 \\
40 & 12.1 & 40 \\
50 & 13.8 & 46 \\
100 & 22.3 & 76 \\
150 & 30.9 & 104 \\
200 & 39.5 & 135 \\
\hline
\end{tabular}

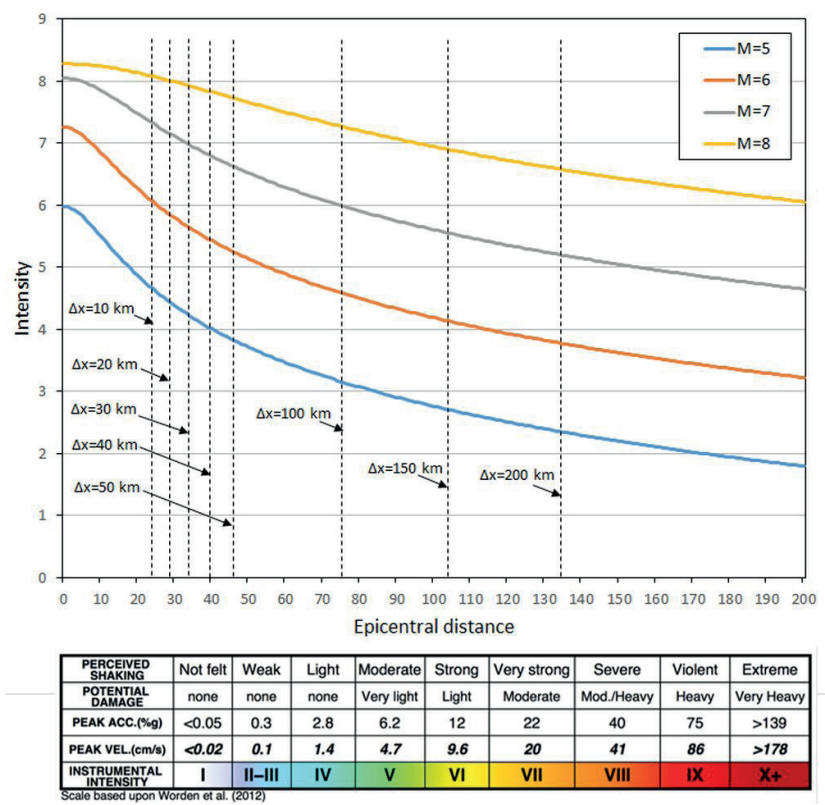

Fig. 1 Median intensity attenuation with epicentral distance for $M=5$, 6,7 , and 8 (Allen et al. [4]) and the radius of blind zones at different station distances most accurate location of the active structures that cause the earthquake. The results of the presented modeling show only an approximate picture, but nevertheless indicate well the limitations of earthquake early warning systems.

The first EEWS was realized in the late 1980s. In Japan, the high-speed Shinkansen trains were automatically slowed down when a strong earthquake was detected in the proximity of the railway tracks. Presently the Japanese earthquake early warning relies on more than 4,000 sensors. During the 2011 large Tohoku earthquake, the earthquake early warning system successfully issued a warning for the largest nearby city, Sendai. The East Japan Railway Company was able to stop the Shinkansen trains before the ground acceleration on the line even exceeded $18 \mathrm{~cm} / \mathrm{s}$, a value required by the company's rules to stop the trains [5]. This is a very strict requirement, corresponding to a value of approximately IV on the intensity scale (see Fig. 1)

In Mexico, following the 1985 Michoacán earthquake that devastated Mexico City, a public system for the city became operational in 1993 [6]. Today, EEW systems are available in numerous countries, including Romania, Taiwan, Turkey, Italy, Switzerland, Chile, Nicaragua, China, and the West Coast of the USA.

\section{The seismological network in Hungary and its role in civil protection}

\subsection{Seismotectonics and seismicity of Hungary}

Hungary is located in the Carpathian basin, which can be found between the seismically active Mediterranean area and the nearly aseismic East European Platform. Its tectonics is determined by the northward movement of the African plate and the counter clockwise rotation of the Adria microplate and the north-northeast directed movement that originates from the rotation.

Seismicity of the country can be regarded as lowto-moderate. Distribution of earthquakes seems to be diffuse; however, there are certain areas where the likelihood of occurrence is higher (Fig. 2). The earthquakes occur in shallow depths, mainly between 6 and $15 \mathrm{~km}$. The largest event occurred in the city of Komárom in 1763; its magnitude was estimated as 6.1 [7].

Statistical studies show that earthquakes causing light damages happen every 15-20 years, but for example, 4 such quakes have occurred in the last 10 years. Stronger, more damaging 5.5-6 magnitude quakes happen about every $40-50$ years [8]. 


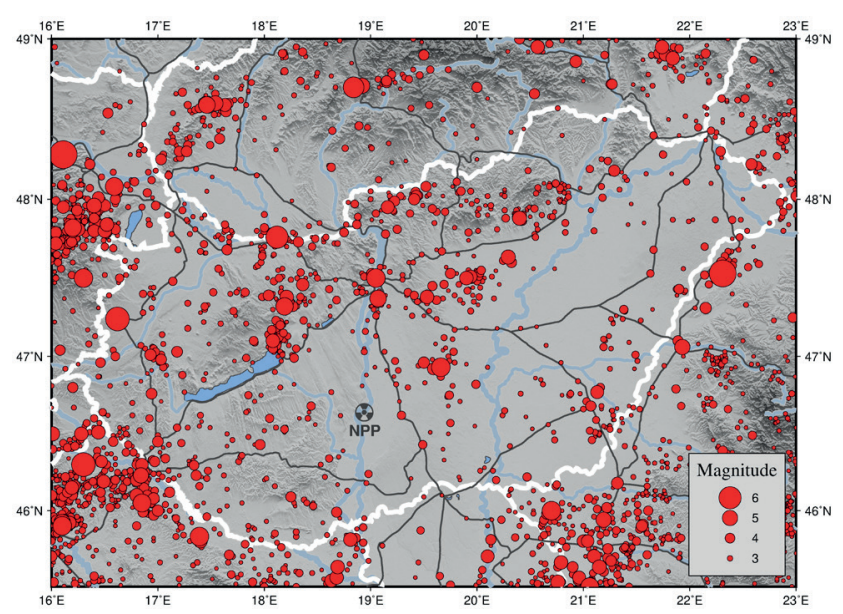

Fig. 2 Seismicity in and around Hungary with the main railway lines marked by gray lines. NPP: Nuclear Power Plant

\subsection{The Hungarian National Seismological Network}

The Hungarian National Seismological Network [9] is operated by the Kövesligethy Radó Seismological Observatory. It is a department of the Research Centre for Astronomy and Earth Sciences, Geodetic and Geophysical Institute. In addition to operating the Network that monitors earthquake activity in Hungary and neighboring areas, the Observatory performs basic and applied scientific research, studies earthquakes, and related phenomena, investigates the Earth's structure, and assesses seismic hazard in Hungary.

In 2020, 15 permanent and 26 temporary stations form the Hungarian National Seismological Network, covering the country quite evenly (Fig. 3). Interstation distances are around $40 \mathrm{~km}$ in western Hungary [10], and somewhat larger in the eastern part of the country. All stations are equipped with broadband seismometers that have flat velocity response from 120 to $0.02 \mathrm{~s}$. The temporary stations are part of two international projects, the AlpArray [11] and the PACASE [12].

Because of the relatively low seismicity, strong motion instruments are not installed in Hungary.

Each station is connected to the Internet and transmits the waveform data in real time to the datacenter in Budapest. In the datacenter, SeisComp3 software [13] performs data processing, which

- collects and archives waveform data,

- picks wave phases automatically or we can pick them manually,

- determines hypocenter and magnitude (automatic and/or manual),

- builds a database of localized seismic events,

- and sends an e-mail automatically to the colleagues and to the main duty of National Directorate for Disaster Management about every localized event.

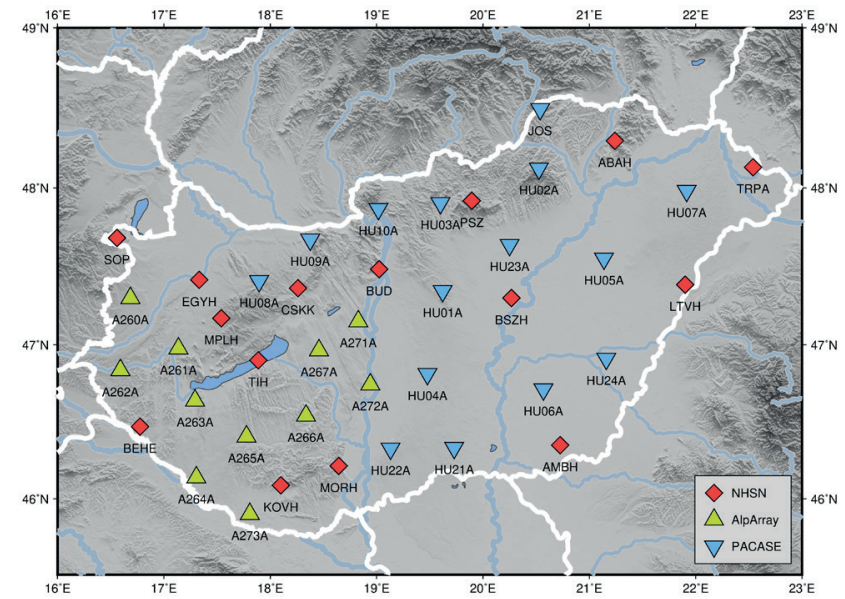

Fig. 3 Permanent and temporary broadband stations in Hungary, in 2020 operated by the Kövesligethy Radó Seismological Observatory

To locate hypocenters, stations of neighboring countries are also used beside Hungarian ones. At average background noise level in the daytime, the minimum magnitude is about 1.25 above which all seismic events are detected in the country. In some regions, it can be even less than 0.75 (Fig. 4).

This sensitive network is suitable for understanding the seismotectonics in the Pannonian Basin, however, poses a problem. Namely the proportion of quarry blasts among registered seismic events has increased with the increasing sensitivity of the network. Therefore, presently it is a very important task to separate manmade events from the earthquakes, which task is supported by an infrasound array installed at the PSZ seismological station.

In Hungary, one nuclear power plant operates, and one is planned on the same site in Paks (Fig. 2). These are located in a low seismicity part of Hungary but known structural lines can be found below the site. In order to monitor the earthquake activity in the vicinity of the Paks Nuclear Power Plant (NPP) a Microseismic Monitoring Network [14]

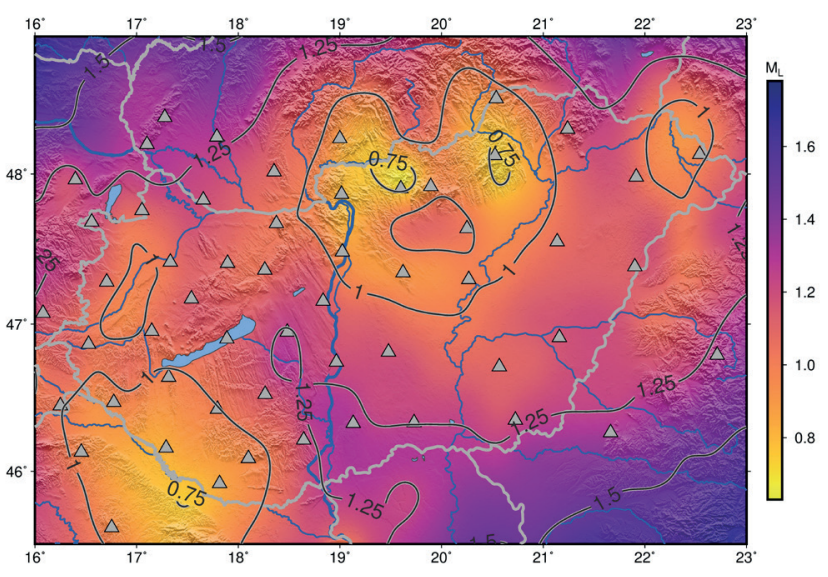

Fig. 4 Detection capability of the Hungarian National Seismological Network supplemented with stations of neighboring countries at average background noise level in the daytime 


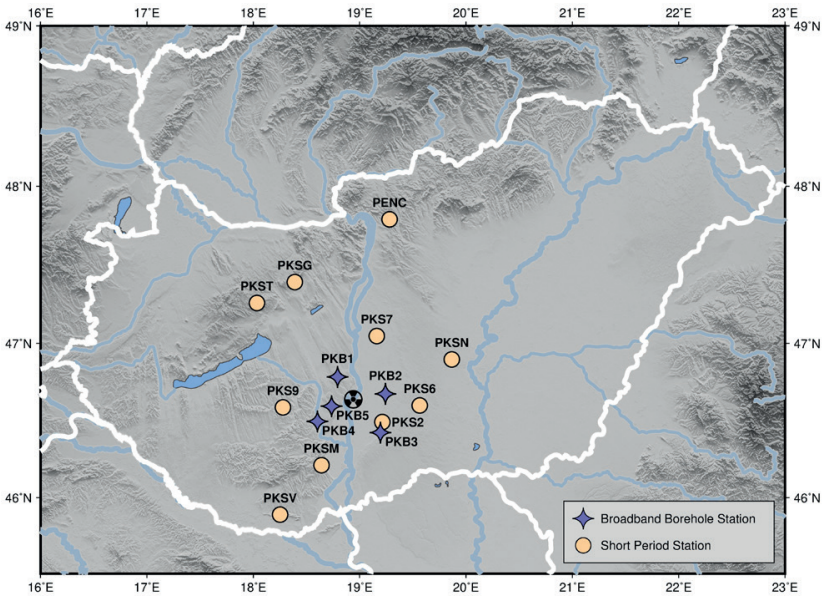

Fig. 5 Microseismic Monitoring Network of Paks NPP

operates around it (Fig. 5). 15 permanent broadband stations of the Hungarian National Seismological Network supplemented by 12 short period stations and 5 borehole stations owned by Paks NPP participate in the monitoring.

The GeoRisk Ltd. operates this Microseismic Monitoring Network and publishes the detected events in their annual seismological bulletin. Fortunately, the experienced seismicity is really low around the Paks NPP (see Fig. 2).

\subsection{The role of the Hungarian National Seismological Network in civil protection}

The researchers of the Observatory maintain a 24-hour professional duty. In the event of a felt earthquake, they send a notice to the National Directorate for Disaster Management and to the Hungarian National News Agency. The population is informed through the website of the Observatory [15] and through the social media $[16,17]$. The contact with citizens is not one-way, the researchers collect macroseismic information through online questionnaires and the Observatory's Facebook page. They also participate in higher education and dissemination of scientific knowledge.

Ground motions that had been caused by the occurred earthquake is also modelled in the Observatory. It includes instrumental parameters such as peak and spectral ground accelerations, peak ground velocity and macroseismic intensity (Fig. 6). This ShakeMap modelling [18] can be made after the occurrence of an earthquake.

The maximum magnitude of earthquakes expected in Hungary is approximately 6.5 [8]. The distribution of seismicity is diffuse, their occurrence cannot be related to clearly known, active fault lines. The largest known earthquake of 6.1 magnitude occurred in Komárom [7], where the main railway line connecting Budapest and Western Europe passes. Likewise, a magnitude 5.6 earthquake
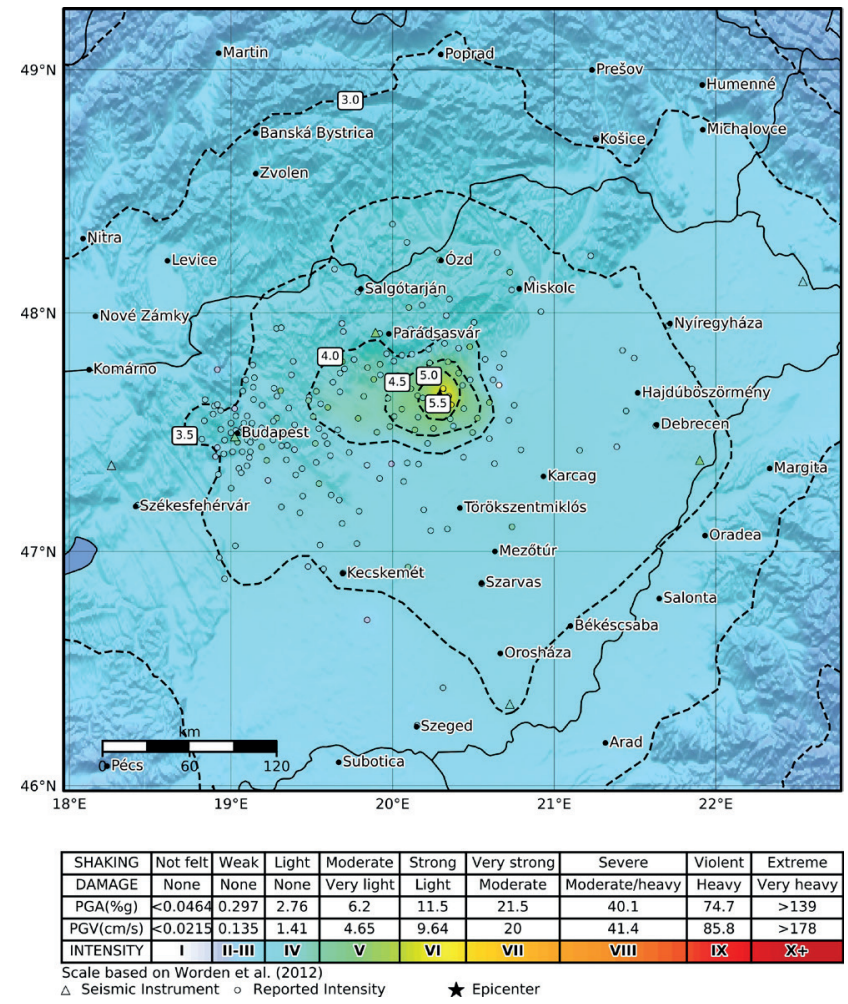

Fig. 6 Macroseismic intensity distribution of 2013 Tenk earthquake (ML4.8) estimated from the measured peak ground velocities at each seismological station and from the macroseismic questionnaire-based assessed intensities.

south of Budapest occurred in 1956 [19, 20]. This event caused liquefaction near the epicenter and notable damage in the capital. If a similar earthquake happened either in Komárom or near Budapest, passenger and freight transport would suffer significant damage causing even more economical loss. For earthquakes of this magnitude, a very dense network of stations is required near the epicenter for the successful operation of an early warning system. However, the largest event occurred in 1763 and seismic activity in the vicinity of its epicenter has been relatively low for the past century. Moreover, we cannot know where the next larger quake will occur. Furthermore, as Hungary is a relatively small country and its critical infrastructure is concentrated in the central part, the warning time in case of a large earthquake would be short and might not even be possible to take effective response measures. Therefore, the establishment of an early warning system does not seem realistic in Hungary at present.

One of the focuses of the research at the Observatory is the seismic hazard assessment. The seismic hazard map of Hungary forms the basis of the National Annex to the Eurocode 8 earthquake safety standard, which has been in force in the country since 2009 . 
Amplification of local geology and methods of seismic microzonation are also studied. Currently preparations are under way for the computation of a new probabilistic seismic hazard map of Hungary since the previous one was made 15 years ago. These include preparation of a new seismotectonic map, review of the earthquake catalogue and developing ground motion prediction equations for the Pannonian basin.

\section{Seismological networks in Kazakhstan and their role in civil protection}

\subsection{Seismotectonics and earthquakes in Kazakhstan}

Kazakhstan is the largest country in Central Asia and the ninth largest in the world. It is bounded by Russia to the north, China to the east, Kyrgyzstan and Uzbekistan to the south, and the Caspian Sea and Turkmenistan to the west. There is considerable variation in topography within the country, with highest and lowest elevations of 7,010 meters in the Tian Shan range and -132 meters in the Caspian Depression, respectively. Seventy percent of the country, including the entire west and most of the south, is either desert or semi-desert. Kazakhstan lies in a region with low to very high seismic hazard. The Tian Shan Mountains in the south eastern part of the country is a large, $\square 1500 \mathrm{~km}$ long and up to $500 \mathrm{~km}$ wide intraplate mountain system that formed between the Tarim Basin and the Kazakh Shield as a result of the India-Asia collision (Fig. 7). This and its adjacent region are in a zone of high seismicity with earthquakes up to about magnitude 9 and surface faulting-up to $300 \mathrm{~km}$ [21].
The seismic hazardous region is home of more than one third of the total population and $40 \%$ of industrial facilities are located here, including the largest industrial and cultural center of the country - the city of Almaty with a population of more than 1.7 million people.

Over the past centuries, many catastrophic earthquakes have occurred in the region. In 1887, the Verny earthquake with a magnitude of about 7.3 had its epicenter a few kilometers west of Almaty. Only 2 years later, in 1889, the Chilik earthquake, with a magnitude of $\mathrm{M}_{\mathrm{W}}=8.3$, ruptured the surface $100 \mathrm{~km}$ to the southeast of Almaty and led to severe shaking in the city. Almaty was heavily damaged by the 1911 Chon Kemin earthquake, with a magnitude of $\mathrm{M}_{\mathrm{W}}=8.2$, which produced up to $\sim 200 \mathrm{~km}$ of surface ruptures and more than $10 \mathrm{~m}$ of slip [22].

Later, the area repeatedly experienced weaker events, some of them are shown in Fig. 8.

The high seismicity zone covers almost $30 \%$ of the territory of the Republic of Kazakhstan. This determines the relevance of the ongoing work on the development of the seismological network of observations.

\subsection{Seismic monitoring and networks in Kazakhstan}

Seismic monitoring is carried out for numerous reasons: in order to create a catalog of earthquakes, which is the basis for all seismological studies; to obtain operational information about earthquakes; to study various predictive parameters of the seismic regime and seismic waves; and to obtain information about the behavior of various types of soils in major earthquakes for engineering seismology.

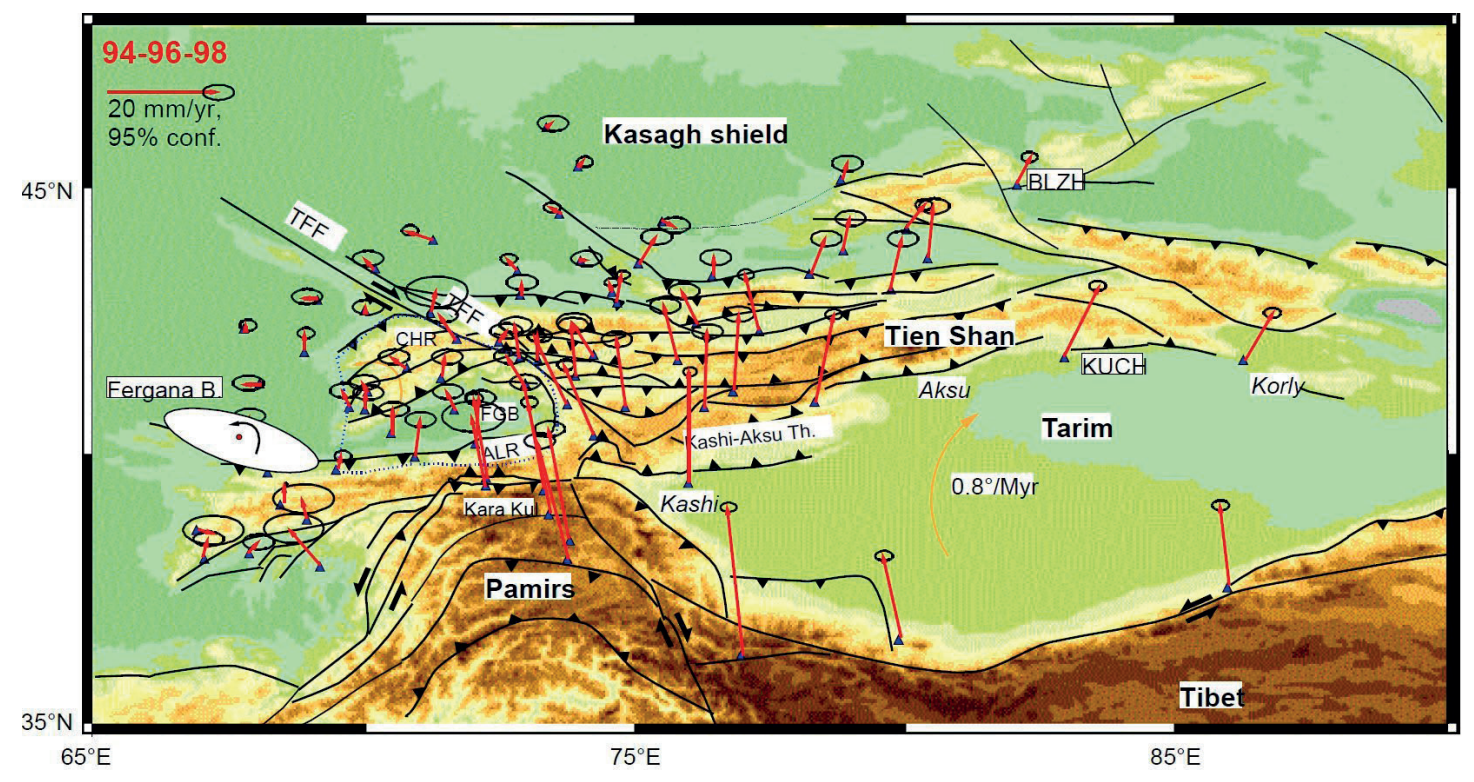

Fig. 7 Seismotectonics of Kazakhstan 


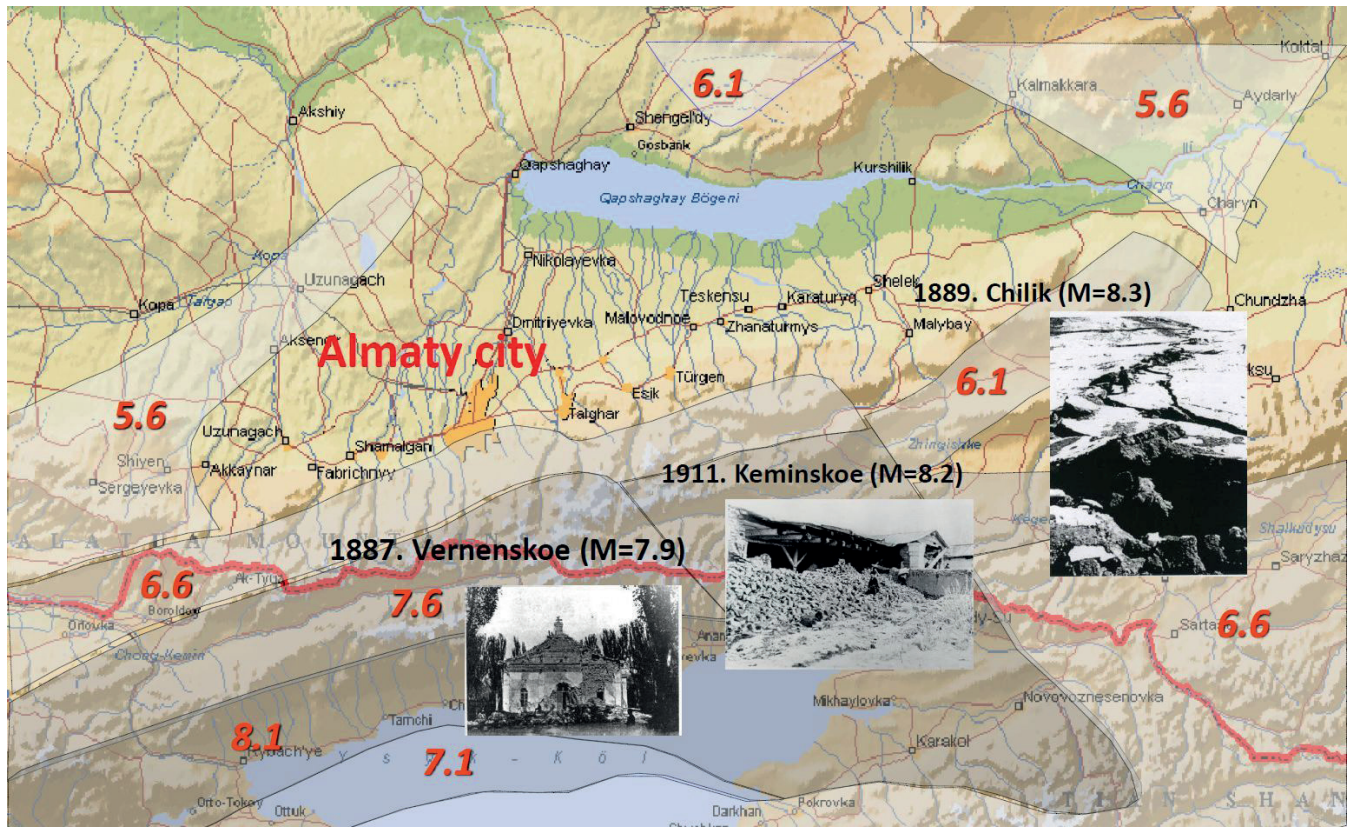

Fig. 8 Major earthquakes in Kazakhstan. The shaded areas show the affected region by each event

Monitoring of seismological information is carried out on a network of seismological stations in Almaty and five regions of the Republic of Kazakhstan: Almaty, East Kazakhstan, Zhambyl, Karaganda and Turkestan.

The earthquake monitoring system includes:

- network of seismological observations;

- network of other geophysical observations;

- network of hydrogeological observation;

- network of observations of current changes on the Earth's surface;

- network of biological observations;

- channels for transmitting information;

- center for collecting, processing and storing information.

The earthquake monitoring system provides:

- urgent reporting service, i.e., timely notification of decision-making bodies of all significant and major earthquakes in the controlled territory;

- registration of earthquakes in the monitored territory and adjacent areas;

- conducting field instrumental observations and obtaining continuous seismic, geophysical, hydrogeological, seismobiological information and data on current movements of the Earth's surface;

- transfer all information received to the data center;

- compilation of earthquake catalogs and bulletins;

- formation of an archive of seismic, geophysical, hydrogeological, seismological information and information about modern movements of the Earth's surface.

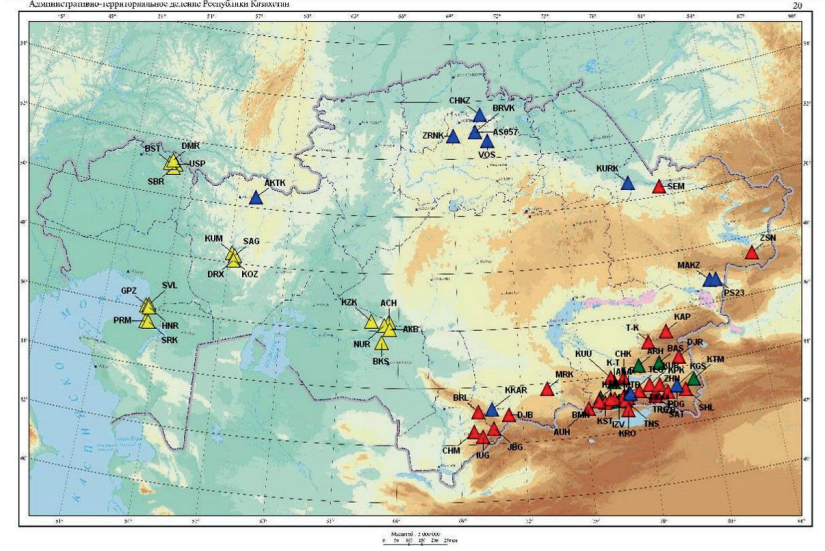

Fig. 9 Seismological network of the Republic of Kazakhstan

Currently, the seismological network of the Republic of Kazakhstan consists of 63 stations (Fig. 9) and points. They perform various types of observations: seismic - on 46 , hydrogeological - on 12; geophysical - on 17 , for current movements of the surface - on 10; biological - on 5 [23].

Seismic observations are carried out in a wide frequency and dynamic range by different types of instruments [24]. The equipment complex includes digital seismic stations with seismometers with different recording periods from $360 \mathrm{~s}$ to $0.02 \mathrm{~s}$ a seismometer system «Vulcan» and digital installations of strong motions ETNA (Fig. 10).

A wide range of seismic instruments is intended for recording weak and strong earthquakes of different remoteness. Long-period equipment (periods from 360 to $10 \mathrm{~s}$ ) allows to register major earthquakes at a distance of several 


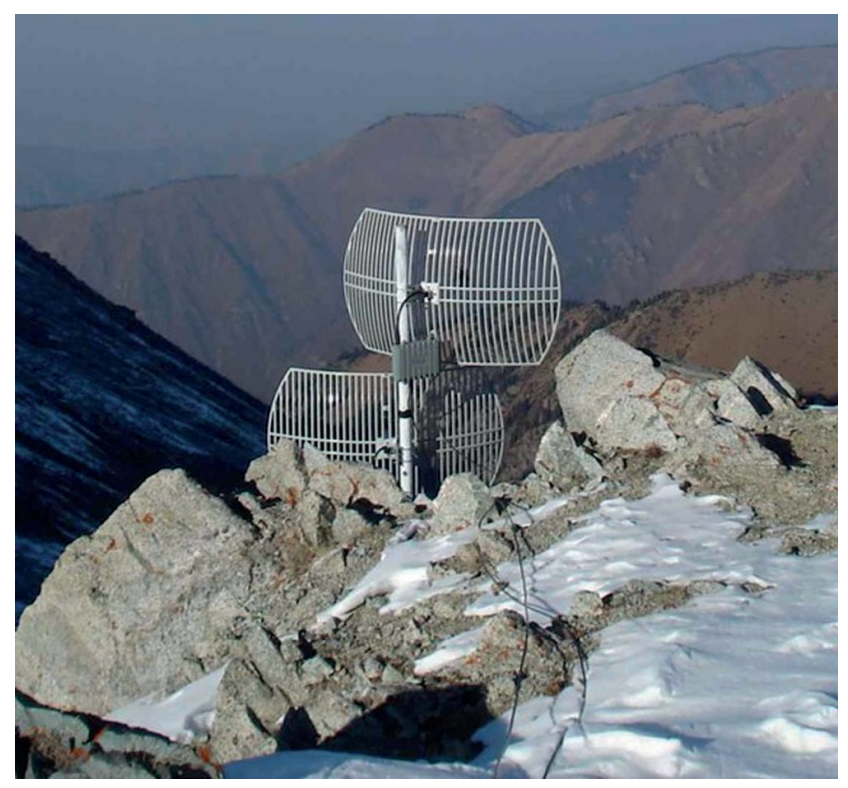

Fig. 10 Big Almaty Lake - ground seismic station

thousand kilometers. Short-period instrumentation (periods from 10 to $0.02 \mathrm{~s}$ ) with high sensitivity records earthquakes in the near-field.

Seismometric system «Vulcan» consists of 11 seismotelemetric stations and processing center located on the Central Seismic Observatory (CSO) «Almaty».

The network of seismic stations ensures the level of representative recording earthquakes of different energy classes.

\subsection{The role of the Kazakh seismological networks in civil protection}

All the stations transmit data to the Almaty CSO in real time. The relevant departments process it and generate reports about occurred earthquakes. In the case of a major, felt earthquake, the operators urgently determine its parameters: origin time; coordinates of the epicenter; earthquake class or magnitude and send it to the decision-making bodies that develop appropriate management decisions to minimize the casualties and economic loss.

Seismological monitoring data is subject to daily operational complex analysis. The complex analysis includes such parameters as seismic, geophysical, hydrogeological data and data on current movements of the Earth's surface from various stations. There are about 70 parameters in total. The purpose of the analysis is identification of shortterm earthquake precursors and assessment of the shortterm (assessment period: 1-30 days) seismic situation. The analysis is based on the behavior of various parameters before earthquakes that occurred in this region in the past.
Despite the development of the seismological network, the lack of seismological stations in the west and north of the country is a problem that impedes to monitor and forecast possible earthquakes. For example, the parameters of the Shalkar earthquake that occurred on April 26, 2008 in the West Kazakhstan region were determined only after using data from the International Center for Seismic Information (Obninsk). This is explained by the fact that the distance to the nearest seismic station "Shymkent" was $1600 \mathrm{~km}$, and to the TSO "Almaty" - $2100 \mathrm{~km}$.

Thus, there is an urgent need to create a wide network of modern seismological monitoring that covers the entire territory of the Republic of Kazakhstan.

The creation of stationary seismic stations with modern equipment requires large financial investments. In the context of the global financial crisis, the government is unable to find the necessary financial resources for the development of the seismic monitoring network.

In this regard, it is proposed to attract the population of the country with modern smartphones to create a seismic monitoring and early warning network.

Smartphones are equipped with GPS, therefore they know their location and the time with high accuracy; and they also have built-in accelerometers. With the appropriate software installed, gadgets can capture seismic waves [25] and transmit information to special processing and warning centers (PWC). In case of an earthquake, a large number of devices would record coherent movements allowing the detection of the event.

When seismic waves occur, gadgets located near the epicenter of an earthquake record them and transmit a signal to the server via base stations, where the software receives and processes the received information and, in case of a threat to the population, automatically transmits it to the mobile app, indicating the time of occurrence, the coordinates of the source and the estimated magnitude of the earthquake, and also issues a command for a centralized shutdown of gas, suspension of the subway and evacuation of passengers if necessary (Fig. 11).

This process occurs automatically (without human participation) in 2-3 seconds from the moment of receipt of information from gadgets, which allows quick notification of the population and special services before the arrival of the main destructive (shear and surface) waves.

To create an effective warning system (excluding false positive warnings) about an impending earthquake, it is necessary to use many hundreds or even thousands of gadgets. Installation of fixed early warning systems costs a lot 


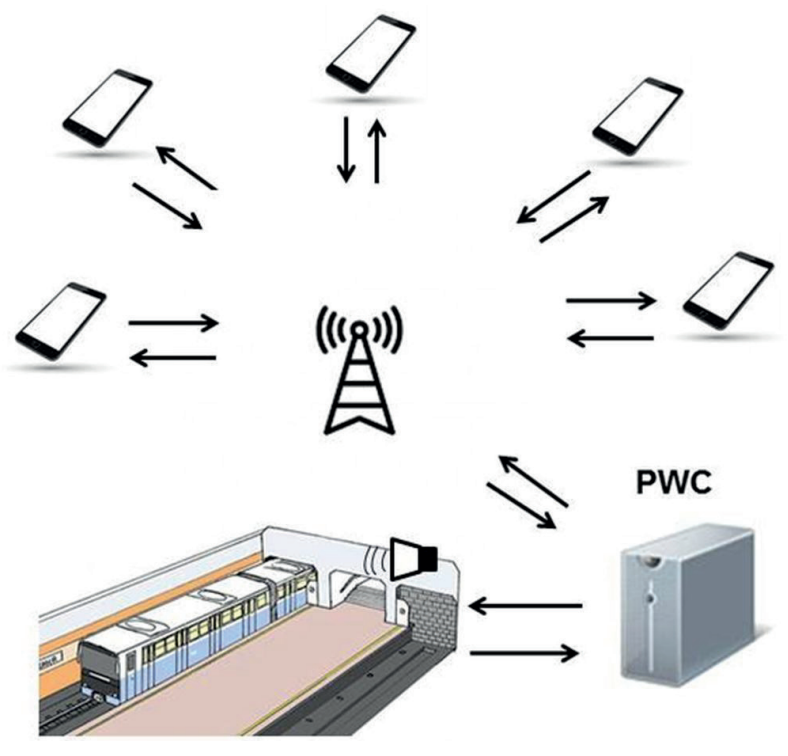

Fig. 11 Smartphone Earthquake Early Warning Diagram

of money. The use of smartphones will not require the purchase of a large number of expensive equipment, and in terms of the effectiveness of early warning it can compete with professional seismological equipment.

\section{Conclusions}

We have described the seismological networks and their role in civil protection in a country with low to moderate seismicity, namely Hungary and in a high seismicity area, Kazakhstan.

The two seismological networks obviously have to differ in their extent. In Hungary, currently the stations are distributed rather equally, thus it is possible to detect very small events; presently much more quarry blasts are recorded than earthquakes. However, in Kazakhstan the observations are concentrated around the known, most hazardous regions.

The focus of seismological work in Hungary is determined by the low level and diffuse nature of seismicity. Therefore, the main goal is seismotectonic mapping and

\section{References}

[1] Havskov, J., Ottemöller, L., Trnkoczy, A., Bormann, P. "Seismic Network", In: Bormann, P. (ed.) New Manual of Seismological Observatory Practice (NMSOP-2), GFZ German Research Centre for Geosciences, Potsdam, Germany, 2012, Chapter 8.

https://doi.org/10.2312/GFZ.NMSOP-2_ch8

[2] Minson, S. E., Meier, M.-A., Baltay, A. S., Hanks, T. C., Cochran, E. S. "The limits of earthquake early warning: Timeliness of ground motion estimates", Science Advances, 4(3), Article ID: eaaq0504, 2018.

https://doi.org/10.1126/sciadv.aaq0504 the support of civil engineering in order to prevent structural failure of the critical infrastructure and dwellings in case of a damaging earthquake occurs. In the meantime, in Kazakhstan considerable efforts are being made by complex analysis of seismological, geophysical, and hydrological data in order to identify precursors of devastating earthquakes, which can be a crucial contribution for decision-making bodies to minimize human and economic loss in case of a disastrous earthquake happens.

We have outlined the operation of earthquake early warning systems and their limitations and showed that seismicity of Hungary does not justify the construction of such a system. However, in Kazakhstan due to the recurring devastating earthquakes it is much needed to develop an EEWS. The extent of the country makes it not reasonable to install permanent seismological stations in a sufficiently dense network covering the whole territory of the hazardous regions, however, modern smartphones are capable of measuring acceleration, and thus they can be used in earthquake detection. Including the public in creating an EEWS would also be a great opportunity to raise awareness and increase efficiency of information dissemination in case of an earthquake.

\section{Acknowledgement}

This article is supported by Hungarian national EFOP3.6.1-16-2016-00014 project "Investigation and development of the disruptive technologies for e-mobility and their integration into the engineering education" (IDEA-E). Its oral presentation was given at the online Workshop on Earthquake Response Management (August 25, 2020) organized by Kokshetau Technical Institute (KTI) and Budapest University of Technology and Economics (BME). The authors thank the anonymous reviewers for their careful review of the manuscript.

[3] Kennett, B. L. N., Engdahl, E. R. "Travel times for global earthquake location and phase identification", Geophysical Journal International, 105(2), pp. 429-465, 1991. https://doi.org/10.1111/j.1365-246X.1991.tb06724.x

[4] Allen, T. I., Wald, D. J., Worden, C. B. "Intensity attenuation for active crustal regions", Journal of Seismology, 16, pp. 409-433, 2012. https://doi.org/10.1007/s10950-012-9278-7

[5] Yamamoto, S., Tomori, M. "Earthquake early warning system for railways and its performance", Journal of Japan Society of Civil Engineers, 1(1), pp. 322-328, 2013. https://doi.org/10.2208/journalofjsce.1.1_322 
[6] Suárez, G., Espinosa $\square$ Aranda, J. M., Cuéllar, A., Ibarrola, G., García, A., Zavala, M., Maldonado, S., Islas, R. "A Dedicated Seismic Early Warning Network: The Mexican Seismic Alert System (SASMEX)", Seismological Research Letters, 89(2A), pp. 382-391, 2018.

https://doi.org/10.1785/0220170184

[7] Zsíros, T. "Seismicity of Komárom-Mór area", Acta Geodaetica et Geophysica Hungarica, 39(1), pp. 121-132, 2004. https://doi.org/10.1556/ageod.39.2004.1.12

[8] Tóth, L., Győri, E., Mónus, P., Zsíros, T. "Seismic hazard in the Pannonian region", In: Pinter, N., Grenerczy, G., Weber, J., Stein, S., Medak, D. (eds.) The Adria Microplate: GPS Geodesy, Tectonics and Hazards. Nato Science Series: IV: Earth and Environmental Sciences, 61, Springer, Dordrecht, Netherlands, 2006, pp. 369-384. https://doi.org/10.1007/1-4020-4235-3_25

[9] Kövesligethy Radó Seismological Observatory (Geodetic and Geophysical Institute, Research Centre for Astronomy and Earth Sciences (MTA CSFK GGI KRSZO)) "Hungarian National Seismological Network", Deutsches GeoForschungsZentrum GFZ, Potsdam, Germany, 1992.

https://doi.org/10.14470/UH028726

[10] Gráczer, Z., Szanyi, G., Bondár, I., Czanik, Cs., Czifra, T., ..., AlpArray Working Group "AlpArray in Hungary: temporary and permanent seismological networks in the transition zone between the Eastern Alps and the Pannonian basin", Acta Geodaetica et Geophysica, 53, pp. 221-245, 2018. https://oi.org/10.1007/s40328-018-0213-4

[11] Hetényi, G., Molinari, I., Clinton, J., Bokelmann, G., Bondár, I., ..., AlpArray Working Group "The AlpArray Seismic Network: A Large-Scale European Experiment to Image the Alpine Orogen", Surveys in Geophysics, 39, pp. 1009-1033, 2018.

https://doi.org/10.1007/s10712-018-9472-4

[12] Hetényi, G., Plomerová, J., Bielik, M., Bokelmann, G., Csicsay, K., ..., Žlebčíková, H. "Pannonian-Carpathian-Alpine Seismic Experiment - an AlpArray Complementary Experiment", [Data set] EIDA, Malmö, Sweden, 2019. https://doi.org/10.7914/SN/ZJ_2019

[13] Helmholtz Centre Potsdam GFZ German Research Centre for Geosciences and gempa GmbH "The SeisComP seismological software package", GFZ Data Services, Potsdam, Germany, 2008. https://doi.org/10.5880/GFZ.2.4.2020.003

[14] GeoRisk Earthquake Engineering "GeoRisk Seismic Network", GeoRisk Earthquake Engineering, Budapest, Hungary, 1995. https://doi.org/10.7914/SN/HM

[15] CSFK Geodéziai és Geofizikai Intézet Kövesligethy Radó Szeizmológiai Obszervatórium (Kövesligethy Radó Seismological Observatory, CSFK GGI), [online] Available at: http://www. seismology.hu

[16] Facebook "ELKH CSFK GGI Kövesligethy Radó Szeizmológiai Obszervatórium (Kövesligethy Radó Seismological Observatory, CSFK GGI)", [online] Available at: https://www.facebook.com/krszo/

[17] Twitter "Szeizmológiai Obsz." (Seismological Obs.), [online] Available: https://twitter.com/szeizmologia

[18] Worden, C. B., Thompson, E. M., Hearne, M. G., Wald, D. J. "ShakeMap 4 Manual", US Geological Survey, Reston, VA, USA, 2020.

https://doi.org/10.5066/F7D21VPQ

[19] Szeidovitz, Gy. "The Dunaharaszti Earthquake January 12, 1956.", Acta Geodaetica et Geophysica and Montanistica, 21, pp. 109-125, 1986.

[20] Bán, Z., Győri, E., Tóth, L., Gráczer, Z., Mahler, A. "Characterization and Liquefaction Hazard Assessment of Two Hungarian Liquefied Sites from the 1956 Dunaharaszti Earthquake", Periodica Polytechnica Civil Engineering, 64(3), pp. 713-721, 2020. https://doi.org/10.3311/PPci.15607

[21] Gupta, S. "Kazakhstan", In: Central Asia and Caucasus Disaster Risk Management Initiative: Risk Assessment for Central Asia and Caucasus, UNDRR, Bangkok, Thailand, Desk Study Review, Chapter 5.4, 2015, pp. 37-40. [online] Available at: https://www. unisdr.org/files/11641_CentralAsiaCaucasusDRManagementInit.pdf [Accessed: 01 October 2020]

[22] Arrowsmith, J. R., Crosby, C. J., Korzhenkov, A. M., Mamyrov, E., Povolotskaya, I., Guralnik, B., Landgraf, A. "Surface rupture of the 1911 Kebin (Chon-Kemin) earthquake, Northern Tien Shan, Kyrgyzstan", Geological Society, London, Special Publications, 432(1), pp. 233-253, 2017. https://doi.org/10.1144/SP432.10

[23] Mikhailova, N. N., Sokolova, I. N. "Monitoring System of the Institute of Geophysical Research of the Ministry of Energy of the Republic of Kazakhstan", Summary of Bulletin of International Seismological Center, 53(I), pp. 27-38, 2019. https://doi.org/10.31905/RK46YGLU

[24] KNDC/Institute Of Geophysical Research "Kazakhstan Network", International Federation of Digital Seismograph Networks, KNDC/ Institute Of Geophysical Research, Almaty, Kazakhstan, 1994. https://doi.org/10.7914/SN/KZ

[25] Kong, Q., Allen, R. M., Schreier, L., Kwon, Y.-W. "MyShake: A smartphone seismic network for earthquake early warning and beyond", Science Advances, 2(2), Article ID: e1501055, 2016. https://doi.org/10.1126/sciadv.1501055 